\title{
MicroRNA-133a inhibits the malignant behavior of glioma via downregulation of matrix metallopeptidase 9
}

\author{
JIANHONG WANG $^{1 *}$, JINGCHENG LI $^{1 *}$, FUQIANG GUO ${ }^{2}$ and YONG YAN ${ }^{3}$ \\ ${ }^{1}$ Department of Neurology, Daping Hospital, Third Military Medical University, Chongqing 400042; \\ ${ }^{2}$ Department of Neurology, The Affiliated Hospital of University of Electronic Science and Technology, \\ Sichuan Provincial People's Hospital, Chengdu, Sichuan 610054; ${ }^{3}$ Department of Neurology, \\ The First Affiliated Hospital of Chongqing Medical University, \\ Chongqing 400016, P.R. China
}

Received March 17, 2015; Accepted January 20, 2016

DOI: $10.3892 / \mathrm{mmr} .2016 .4907$

\begin{abstract}
MicroRNA (miR)-133a expression has been reported to be downregulated in numerous human malignancies. However, the expression levels and function of miR-133a have not yet been investigated in human glioma. In the present study, the expression of miR-133a was analyzed by reverse transcription-quantitative polymerase chain reaction. Following transfection of miR-133a, cell proliferation, cell migration, cell invasion and luciferase assays, and western blot analysis were conducted in glioma cell lines. The present study demonstrated that miR-133a was downregulated in human glioma tissues compared with in normal adjacent tissues. In addition, the results indicated that miR-133a was likely to directly target matrix metallopeptidase 9 in glioma. These results suggest that miR-133a may be considered as a target for the treatment of human glioma.
\end{abstract}

\section{Introduction}

Gliomas are solid tumors of the central nervous system, which represent $>30 \%$ of central nervous system tumors and account for $70 \%$ of malignant primary brain tumors $(1,2)$. It is estimated that there are 20,000 newly diagnosed cases each year in the USA (2). Histologically, gliomas are divided into oligodendrogliomas, astrocytomas, anaplastic astrocytomas, glioblastomas, and numerous other subtypes (3). Malignant gliomas, including anaplastic astrocytomas and glioblastoma multiforme are the most common types of primary brain

Correspondence to: Professor Yong Yan, Department of Neurology, The First Affiliated Hospital of Chongqing Medical University, 1 Youyi Road, Chongqing 400016, P.R. China

E-mail: yongyandoctor@163.com

*Contributed equally

Key words: glioma, microRNA-133a, matrix metallopeptidase 9, microRNA tumor, accounting for $\sim 60 \%$ of gliomas $(4,5)$. The standard therapeutic strategies for glioma treatment, including surgical resection, and adjuvant radiotherapy and chemotherapy, have improved the 5-year survival rates from 2 to $10 \%$; however, the prognosis for patients diagnosed at an advanced stage remains poor $(6,7)$. It has previously been demonstrated that dysregulated tumor suppressor genes or oncogenes are closely associated with the development and progression of glioma (8). Therefore, more effective therapeutic strategies and targets for the treatment of glioma should be developed, alongside an increased understanding of the molecular pathogenesis of glioma.

Previous studies have indicated that microRNAs (miRNAs) are important in numerous aspects of human cancer (9-12). miRNAs are a class of non-coding RNA molecules (length, 18-25 nucleotides), which induce mRNA degradation and suppress protein translation, predominantly by binding to the seed sequences in the 3 '-untranslated region of mRNAs $(13,14)$. miRNAs influence various physiological and pathological processes, including proliferation, differentiation, apoptosis, metabolism, migration and invasion $(11,15)$.

It has previously been estimated that miRNAs are involved in almost every biological process by targeting $\sim 30 \%$ of protein-coding genes in the human genome (16). Since the first miRNA expression profiles were obtained from a range of cancer types using bead-based flow cytometry, hundreds of evolutionarily conserved miRNAs have been identified in different species, including plants, animals and viruses $(10,17)$. There is also an increasing amount of evidence suggesting that miRNAs may function as tumor suppressors and oncogenes (18). Downregulated miRNAs in cancer may normally function as tumor suppressor genes and inhibit cancer by regulating oncogenes. Conversely, upregulated miRNAs in cancer may function as oncogenes by negatively regulating tumor suppressors (19). Therefore, the identification of miRNA target genes is critical to understand the function of miRNAs in cancer development and progression. It has also been suggested that miRNAs may be a target for cancer therapy.

The expression levels of miR-133a have been reported to be downregulated in numerous human malignancies (20-28); however, to the best of our knowledge, the role of miR-133a 
in human glioma has not yet been investigated. In the present study, the expression levels and effects of miRNA-133a on human glioma were examined. The results of the present study demonstrated that miR-133a was downregulated in human glioma tumor tissues compared with their normal adjacent tissues (NATs), and miR-133a was able to suppress cell proliferation, migration and invasion by directly targeting matrix metallopeptidase 9 (MMP9). These findings may have therapeutic implications, and may be useful for the development of novel treatments for human glioma.

\section{Materials and methods}

Clinical specimens. The present study was approved by the ethics committee of The First Affiliated Hospital of Chongqing Medical University (Chongqing, China) and informed consent was obtained from all patients. The glioma and NAT specimens for reverse transcription-quantitative polymerase chain reaction (RT-qPCR) were obtained from 50 patients (32 male and 28 female; age range, 37-84 years) who had undergone surgery at Daping Hospital (Chongqing, China) between January 2010 and December 2014. Of the 50 gliomas, 22 were classified as low-grade [World Health Organization (WHO) I and WHO II] gliomas and 28 were classified as high-grade (WHO III and WHO IV) gliomas (29). None of the patients had received chemotherapy, immunotherapy or radiotherapy prior to specimen collection. Tissues were snap-frozen in liquid nitrogen and stored at $-80^{\circ} \mathrm{C}$.

Cell culture and transfection. The U251 and U87 human glioma cell lines were obtained from the Shanghai Institute of Biochemistry and Cell Biology (Shanghai, China). U251 and U87 cells were cultured in Dulbecco's modified Eagle's medium (DMEM) supplemented with $10 \%$ heat-inactivated fetal bovine serum (Gibco; Thermo Fisher Scientific, Inc., Waltham, MA, USA) at $37^{\circ} \mathrm{C}$ in a $5 \% \mathrm{CO}_{2}$ cell incubator.

Mature miR-133a mimics, negative control (NC) miRNA mimics and the luciferase reporter plasmid were designed and synthesized by Shanghai GenePharma Co., Ltd. (Shanghai, China). The sequence of miR-133a mimics was 5'-UUUGGU CCCCUUCAACCAGCUG-3'. The sequence of NC mimics was 5'-UUCUCCGAACGUGUCACGUTT-3'. Transient transfection was performed using Lipofectamine ${ }^{\circledR} 2000$ (Invitrogen; Thermo Fisher Scientific, Inc.), according to the manufacturer's protocol.

$R N A$ isolation and $R T-q P C R$ analysis. The tissues were homogenized and the total RNA was extracted from tissues with TRIzol ${ }^{\circledR}$ (Invitrogen; Thermo Fisher Scientific, Inc.), according to the manufacturer's protocol. The concentration and purity of all RNA samples were measured using an ND-2000 spectrophotometer (NanoDrop Technologies; Thermo Fisher Scientific, Inc., Wilmington, DE, USA). RT-qPCR analysis was performed using One Step SYBR ${ }^{\circledR}$ PrimeScript $^{\mathrm{TM}}$ miRNA RT-PCR kit (Takara Bio, Inc., Otsu, Japan) in a CFX96 ${ }^{\mathrm{TM}}$ Real-Time system and a C1000 ${ }^{\mathrm{TM}}$ Thermal Cycler (both Bio-Rad Laboratories, Inc., Hercules, CA, USA) according to the manufacturers' protocols. The primers were obtained from Guangzhou RiboBio Co., Ltd. (Guangzhou, China) Each reaction was performed in a final volume of $25 \mu \mathrm{l}$. The cycling conditions were as follows: $42^{\circ} \mathrm{C}$ for $5 \mathrm{~min} ; 9^{\circ} \mathrm{C}$ for $10 \mathrm{sec}$; and 40 cycles of $95^{\circ} \mathrm{C}$ for $5 \mathrm{sec}, 55^{\circ} \mathrm{C}$ for $30 \mathrm{sec}$ and $70^{\circ} \mathrm{C}$ for $30 \mathrm{sec}$. Each sample was analyzed in triplicate and the data were normalized using the endogenous U6 small nuclear RNA. The relative expression of miR-133a was analyzed by use of the $2^{-\Delta \Delta \mathrm{Cq}} \operatorname{method}(30)$.

Cell proliferation assay. Cell proliferation was determined using Cell Counting kit-8 (CCK-8) detection kit (Dojindo Molecular Technologies, Inc., Kumamoto, Japan). The transfected cells (with miR-133a mimics or NC) were seeded at a density of $3 \times 10^{3}$ cells/well into 96 -well plates. Cell proliferation was assayed every $24 \mathrm{~h}$ for 5 days. Briefly, $10 \mu \mathrm{l} \mathrm{CCK}-8$ solution was added to each well and incubated at $37^{\circ} \mathrm{C}$ for $2 \mathrm{~h}$. Absorbance was measured at $450 \mathrm{~nm}$ in an ELISA reader (Elx800; Bio-Rad Laboratories, Inc.). The suppression rate of proliferation was calculated using the following formula: Suppression rate $=\left(1-\mathrm{OD}_{\text {miR-133a }} / \mathrm{OD}_{\text {miR-NC }}\right) \times 100 \%$. OD indicates optical density. All the experiments were performed in triplicate.

Cell migration and invasion assays. Migration and invasion of glioma cell lines were assessed using Transwell chambers with an $8-\mu \mathrm{m}$ pore polycarbonate membrane (Costar; Corning Incorporated, Corning, NY, USA). For the migration assay, $5 \times 10^{4}$ transfected cells (with miR-133a mimics and NC) were harvested and suspended in $200 \mu \mathrm{l}$ DMEM with $0.1 \%$ FBS. These cells were placed into the upper chamber. A volume of $0.5 \mathrm{ml}$ DMEM with $20 \% \mathrm{FBS}$ was then added to the lower chamber as a chemoattractant. For the invasion assay, $5 \times 10^{4}$ transfected cells were placed into the upper chamber, which was coated with Matrigel (BD Biosciences, San Jose, CA, USA). A volume of $0.5 \mathrm{ml}$ DMEM with $20 \% \mathrm{FBS}$ was then added to the lower chamber as a chemoattractant. Cells were incubated for a further $12 \mathrm{~h}$ for the migration assay and $24 \mathrm{~h}$ for the invasion assay. In the two assays, the invaded cells on the lower surface were fixed with $100 \%$ methanol (Shanghai Macklin Biochemical Co., Ltd., Shanghai, China), stained with $0.5 \%$ crystal violet (Beyotime Institute of Biotechnology, Haimen, China), and were then counted under an inverted microscope (CKX41; Olympus Corporation, Tokyo, Japan) to calculate the relative numbers (magnification, x100). Each experiment was repeated at least three times.

Western blotting. Mouse anti-human monoclonal primary antibodies against MMP9 (dilution, 1:1,000; sc-21733) and $\beta$-actin (dilution, 1:1,000; sc-47778), which were obtained from Santa Cruz Biotechnology, Inc. (Dallas, TX, USA), were used in the present study. Following $72 \mathrm{~h}$ of transfection with miR-133a or NC, the cells were washed twice with ice-cold phosphate-buffered saline and lysed with radioimmunoprecipitation assay lysis buffer [50 mM Tris-HCl (pH 7.4), 1\% NP-40, $0.25 \%$ Na-deoxycholate, $150 \mathrm{mM} \mathrm{NaCl}, 1 \mathrm{mM}$ EDTA, $1 \mathrm{mM}$ phenylmethylsulfonyl fluoride, $1 \mu \mathrm{g} / \mathrm{ml}$ aprotinin, $1 \mu \mathrm{g} / \mathrm{ml}$ leupeptin, $1 \mu \mathrm{g} / \mathrm{ml}$ pepstatin, $1 \mathrm{mM} \mathrm{Na} \mathrm{VO}_{4}$ and $\left.1 \mathrm{mM} \mathrm{NaF}\right]$. The protein concentration was measured using a bicinchoninic acid assay kit (Beyotime Institute of Biotechnology). Equal quantities of protein $(20 \mu \mathrm{g})$ were separated by $10 \%$ sodium dodecyl sulfate-polyacrylamide gel electrophoresis and electrotransferred to polyvinylidene difluoride membranes (Beyotime Institute of Biotechnology). For western blotting, the 
membranes were blocked with 5\% skimmed milk and incubated with the primary antibodies at dilutions specified by the manufacturer's protocols at $4^{\circ} \mathrm{C}$ overnight. The membranes were washed with Tris-buffered saline with $0.5 \%$ Tween 20 (TBST; Beyotime Institute of Biotechnology) and then incubated with a goat anti-mouse horseradish peroxidase-conjugated secondary antibody (1:10,000; Santa Cruz Biotechnology, Inc.; sc-2005) in TBST. The protein bands were developed with enhanced chemiluminescence reagents (Pierce Biotechnology, Inc., Rockford, IL, USA) and imaged with a FluorChem imaging system (version 4.1.0; Alpha Innotec, San Leandro, CA, USA).

Luciferase assay. The U251 and U87 cells were transfected with $0.5 \mu \mathrm{g}$ MMP9-3'-UTR-Wild type or MMP9-3'-UTR-Mutant, and $40 \mathrm{nmol}$ miR-133a mimics or NC in a 12-well plate using Lipofectamine $^{\circledR} 2000$, according to the manufacturer's protocol. The activities of the firefly and Renilla luciferases in cell lysates were determined using the Dual-Luciferase Reporter assay system (Promega Corporation, Madison, WI, USA) $48 \mathrm{~h}$ post-transfection. The firefly luciferase activity was normalized to the Renilla luciferase activity for each transfected well. Each reporter plasmid was transfected at least three times (on different days) and each sample was assayed in triplicate.

Statistical analysis. Data are presented as the mean \pm standard deviation. Data were analyzed using Student's t-test and analysis of variance in Stata 10.0 (StataCorp LP, College Station, TX, USA). $\mathrm{P}<0.05$ was considered to indicate a statistically significant difference.

\section{Results}

miR-133a is downregulated in glioma tumor tissues compared with NATs. miR-133a expression levels were detected in all glioma tissues and NATs using RT-qPCR. As presented in Fig. 1A, miR-133a was significantly decreased in glioma tissues compared with NATs $(\mathrm{P}<0.01)$. These results indicate that miR-133a may have an important role in glioma.

Furthermore, the present study investigated whether the expression levels of miR-133a were associated with tumor grade and stage. The statistical analysis demonstrated that the expression levels of miR-133a were significantly lower in high-grade glioma (WHO III and WHO IV) compared with in low-grade glioma (WHO I and WHO II; Fig. 1B; P<0.01).

miR-133a suppresses cell proliferation in U251 and U87 glioma cells. To investigate the effects of miR-133a on glioma cell proliferation, the CCK-8 assay kit was used. Upregulation of miR-133a markedly inhibited cell proliferation in glioma U251 and U87 cells (Fig. 2; P<0.01). These results indicate that miR-133a may function as a tumor suppressor in human glioma.

miR-133a suppresses cell migration and invasion in U251 and U87 glioma cells. To determine the influence of miR-133a on tumor cell migration and invasion, the Transwell assay was used. As shown in Fig. 3, the migratory and invasive ability of U251 and U87 glioma cells transfected with miR-133a was markedly decreased compared with those transfected with $\mathrm{NC}$ $(\mathrm{P}<0.01)$. These results indicate that miR-133a may decrease the migration and invasion of glioma cells.

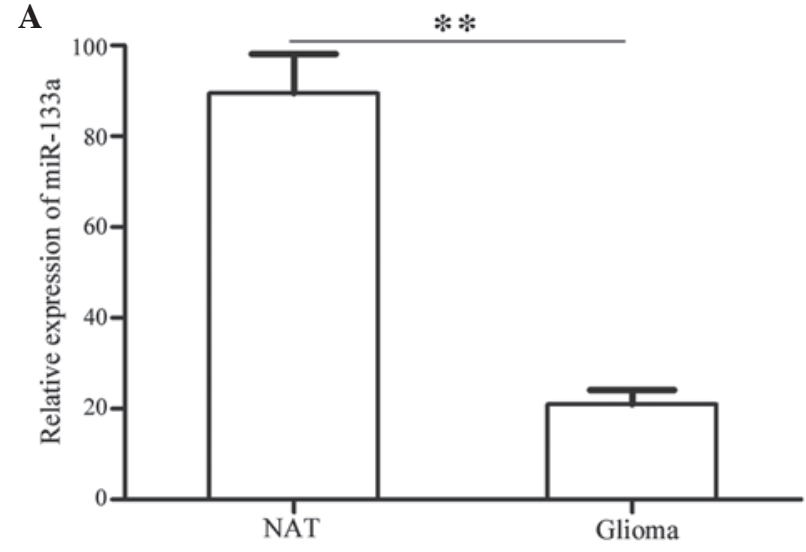

$\mathbf{B}$

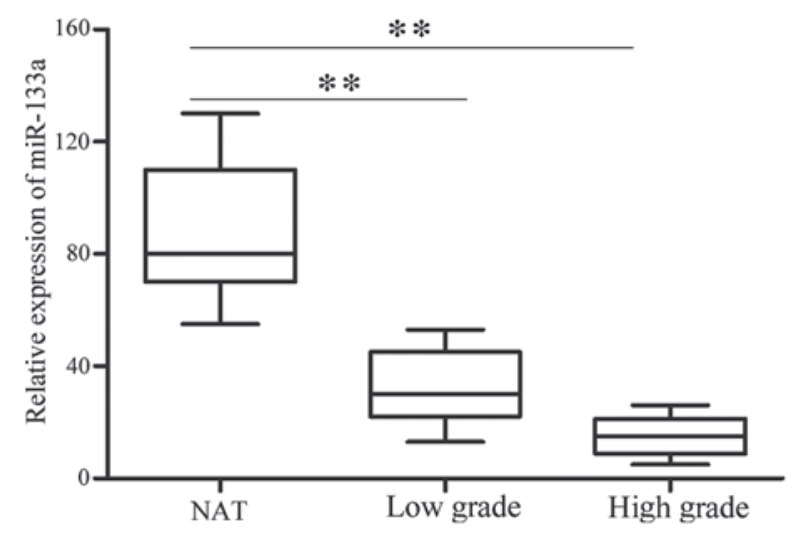

Figure 1. (A) Reverse transcription-quantitative polymerase chain reaction analysis of miR-133a expression in glioma tissues and NATs. miR-133a expression is decreased in glioma tissues. Data are presented as the mean \pm standard deviation. (B) Expression levels of miR-133a were significantly lower in high-grade glioma (WHO III and IV) compared with in low-grade glioma (WHO I and II). Data is presented in the box plot as mean and range. ${ }^{* *} \mathrm{P}<0.01$. NAT, normal adjacent tissue; WHO, World Health Organization; miR, microRNA.

MMP9 is a direct target gene of miR-133a in glioma cells. To identify the target of miR-133a in glioma cells, TargetScan (http://www.targetscan.org) was used and MMP9 was predicted to be a target of miR-133a (Fig. 4A). To verify whether miR-133a directly targets MMP9, luciferase reporter assays were performed. As presented in Fig. 4B, miR-133a significantly inhibited the luciferase activity of wild-type MMP9 but not that of mutant MMP9 in U251 and U87 glioma cell lines $(\mathrm{P}<0.01)$.

Furthermore, western blotting was performed to investigate whether MMP9 was decreased following transfection of U251 and U87 glioma cells with miR-133a. As presented in Fig. 4C, MMP9 was significantly downregulated in U251 and U87 glioma cells post-transfection with miR-133a $(\mathrm{P}<0.01)$. These results suggest that MMP9 may be a direct target gene of miR-133a in the U251 and U87 glioma cell lines.

\section{Discussion}

Previous studies have indicated that miRNAs are aberrantly expressed in several types of human cancer, and are widely involved in the regulation of cancer development $(30,31)$. However, the underlying molecular mechanisms by which miRNAs regulate carcinogenesis and cancer progression remain 

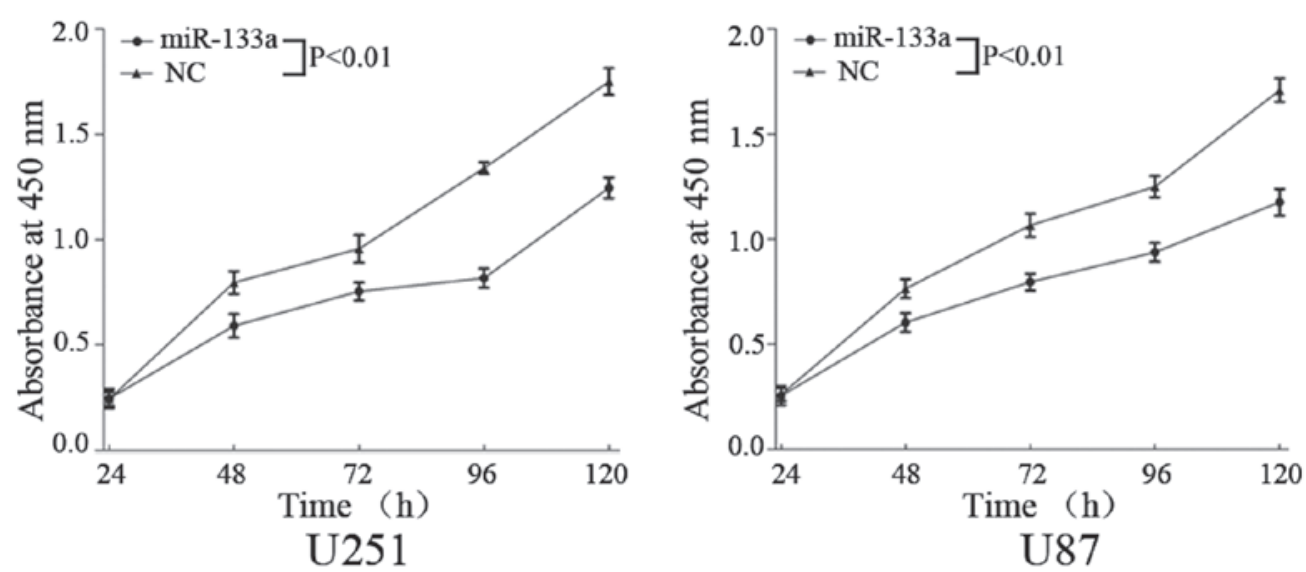

U87

Figure 2. Cell Counting Kit-8 assay was performed to determine cell viability. Upregulation of miR-133a markedly suppressed cell proliferation in U251 and U87 glioma cell lines. Data are presented as the mean \pm standard deviation. miR, microRNA; NC, negative control.
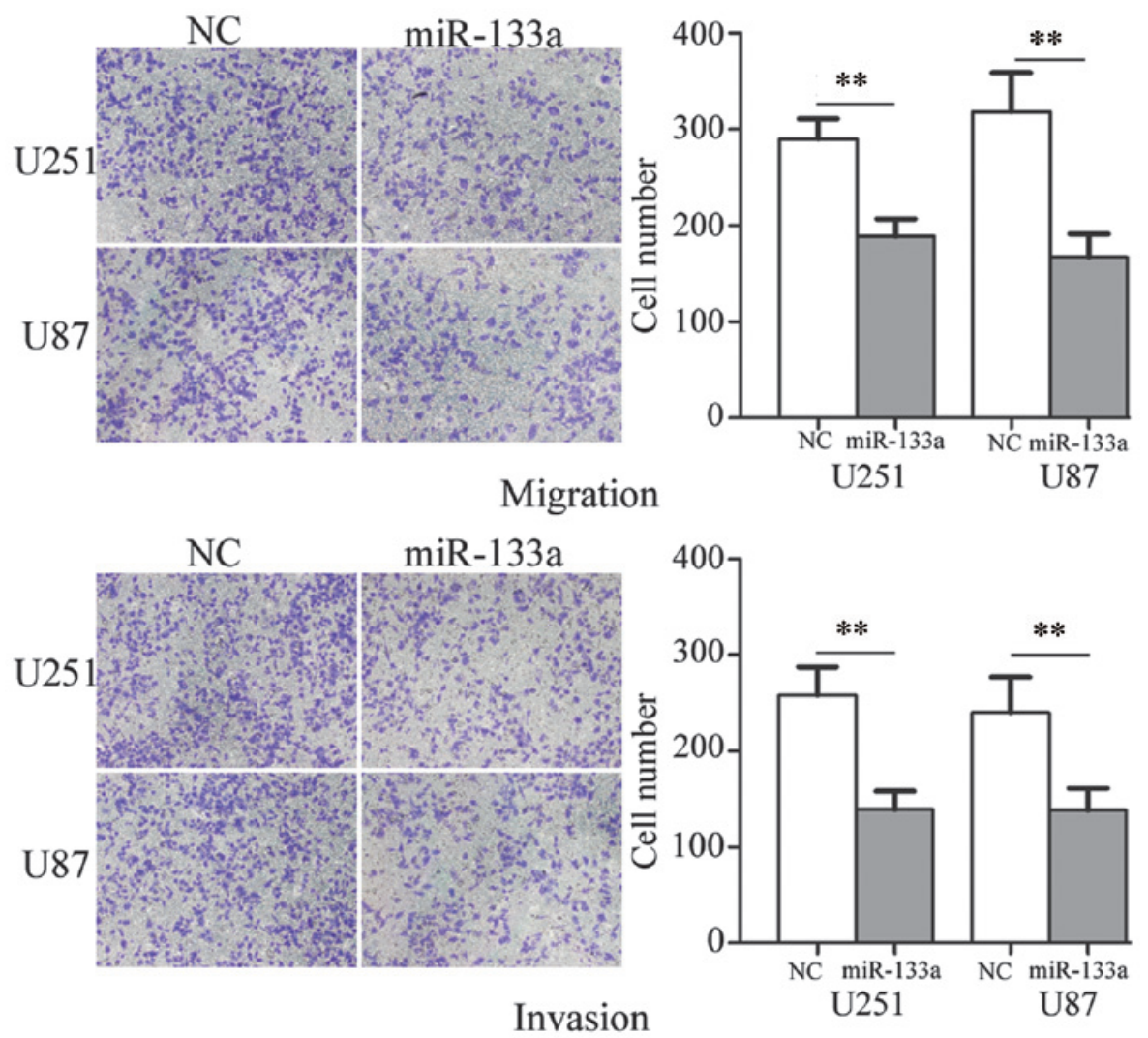

Figure 3. miR-133a inhibited cell migration and invasion in the U251 and U87 glioma cell lines. Subsequent to a $12 \mathrm{~h}$ incubation, the number of U251 and U87 cells that traversed the Transwell membrane was significantly decreased following transfection with miR-133a. Subsequent to a $24 \mathrm{~h}$ incubation, the number of U251 and U87 cells that traversed the Matrigel-precoated Transwell membrane was significantly decreased following transfection with miR-133a. Data are presented as the mean \pm standard deviation. ${ }^{* *} \mathrm{P}<0.01$. NC, negative control; miR, microRNA.

to be elucidated. Investigation into differentially expressed miRNAs in cancer tissue samples has provided important information to aid understanding of carcinogenesis (32). The present study is, to the best of our knowledge, the first to demonstrate that miR-133a is downregulated in human glioma, which led to the hypothesis that miR-133a may exert a tumor-suppressive effect in human glioma development and progression. By analyzing overexpression of miR-133a in human glioma cell lines, the present study verified that miR-133a reduced cell proliferation, migration and invasion, also suggesting a tumor suppressive role of miR-133a. Therefore, these results may have clinical implications in the future.

miR-133 is one of the most studied and best characterized miRNAs. miR-133a and miR-133b are on chromosome 18 in the same bicistronic unit (20). miR-133a has been verified as a muscle-specific miRNA, which may modulate myoblast differentiation and participate in heart and myogenic diseases $(33,34)$. It has been identified as downregulated in numerous human malignancies, including prostate cancer (21), bladder cancer (20), renal cell carcinoma (22), pancreatic 
A

Position 43-49 of MMP9 3' UTR

hsa-miR-133a

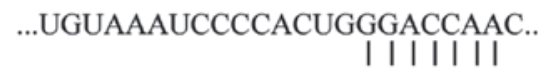

$\mathbf{B}$
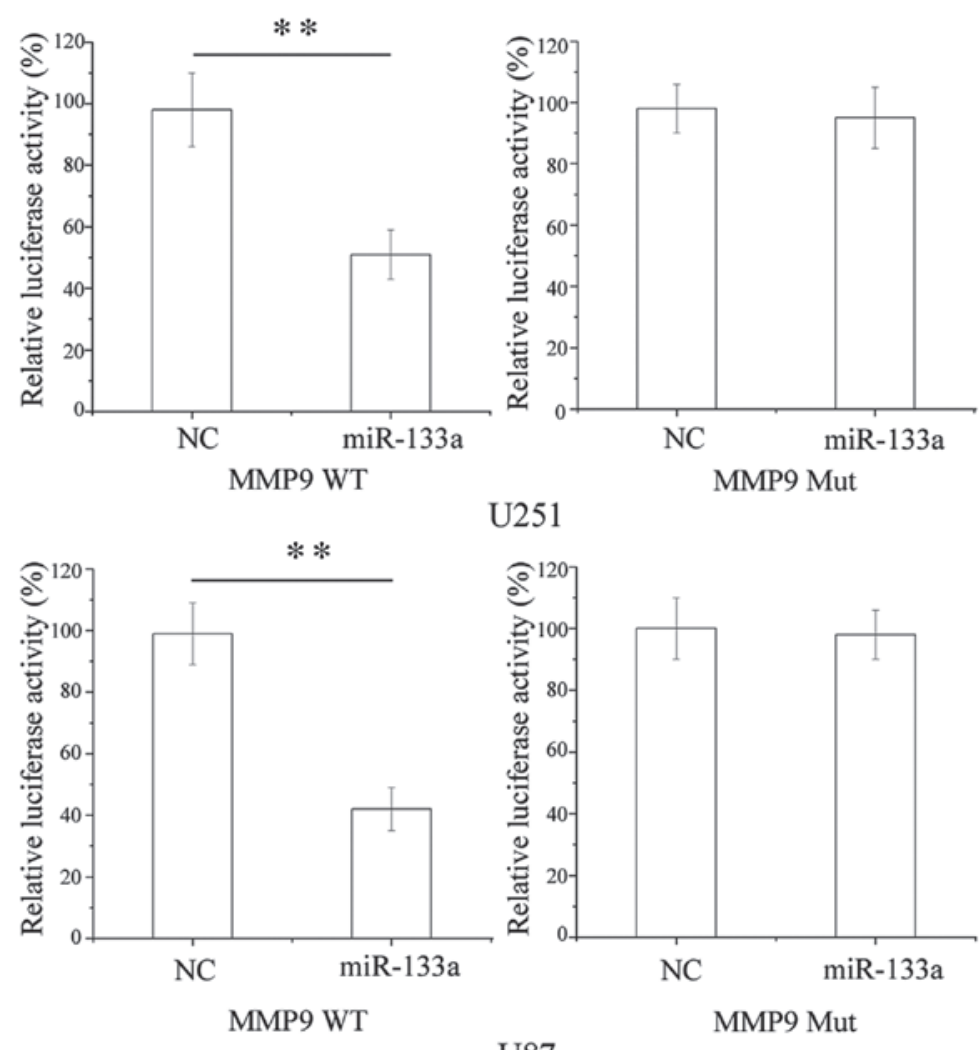

C
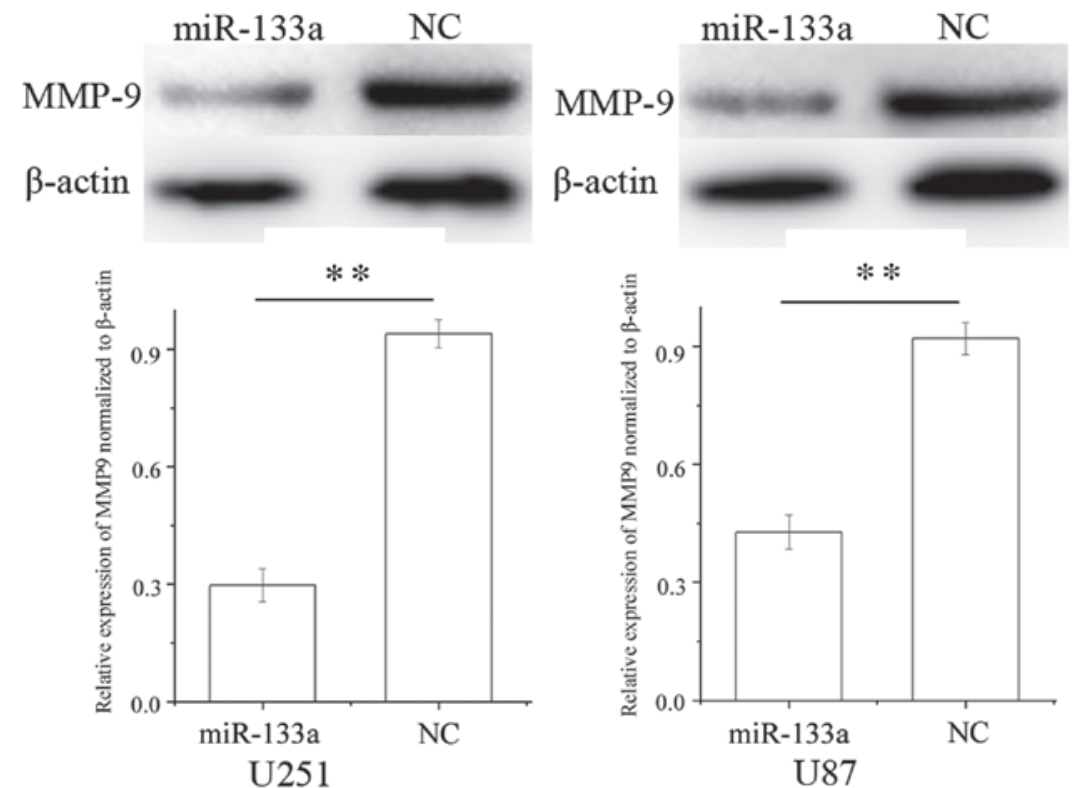

Figure 4. (A) TargetScan determined that MMP9 mRNA contains a seven-nucleotide seed match for miR-133a at position 43-49 of the MMP9 3'-UTR. (B) MMP9 may be a direct target of miR-133a in vitro. Overexpression of miR-133a significantly inhibited the WT but not the Mut luciferase activity of MMP9 in U251 and U87 glioma cell lines. (C) MMP9 was significantly reduced in U251 and U87 glioma cells following transfection with miR-133a. Data are presented as the mean \pm standard deviation. ${ }^{* *} \mathrm{P}<0.01$. UTR, untranslated region; MMP9, matrix metallopeptidase 9; miR, microRNA: WT, wild-type; Mut, mutant.

ductal adenocarcinoma (23), esophageal squamous cell carcinoma (24), ileal carcinoid tumors (25), rhabdomyosarcoma (26), and hepatocellular and lung carcinomas $(27,28)$. Recent studies have suggested that miR-133a inhibits cell proliferation, 
migration and invasion in bladder and prostate cancer by targeting epidermal growth factor receptor (EGFR) and its downstream effector proteins $(20,21)$. Previous studies have reported the effect of ectopic miR-133a on inhibition of cancer cell growth in lung squamous cell carcinoma, maxillary sinus squamous cell carcinoma, tongue squamous cell carcinoma, esophageal squamous cell carcinoma, renal cell carcinoma and rhabdomyosarcoma $(22,26,32,35-37)$. It has been suggested that miR-133a may be important in these types of cancer and may serve as a potential therapeutic target for their treatment.

Identification of miR-133a target genes is critical for understanding its role in tumorigenesis. Studies have demonstrated that it may regulate oncogenic transcripts in human cells, including EGFR (21), moesin (38), Sp1 transcription factor (39), fascin actin-bundling protein 1 (40), insulin like growth factor-1 (41), glutathione S-transferase pi 1 (42), LIM and SH3 protein 1 (43) and transgelin 2 (44). The present study hypothesized that miR-133a may function as a tumor suppressor via downregulation of MMP9 in glioma. miR-133a transfection resulted in decreased cell viability, and reduced migration and invasion in human glioma cells. These results suggested that it may be useful in the development of novel molecular markers and therapeutic strategies to inhibit metastasis in glioma.

MMP9, which is a member of the zinc-dependent endopeptidases family, is a $92 \mathrm{kDa}$ type IV collagenase and a key component in the basement membrane (45-47). Due to its extracellular matrix degrading characteristics, it has been demonstrated that upregulation of MMP9 facilitates metastatic spread of numerous human malignancies, and it appears to be one of the most important molecules to directly promote cancer metastasis (48). MMP9 has been shown to be enhanced or activated by oncogenic proteins in several types of human cancer, including prostate, breast, pancreatic and bladder cancer (47,49-52). MMP9 expression has also been detected in human glioma tissues, where it may facilitate multiple biological events required for glioma progression, including invasion, migration and dissemination of glioma cells (53). Furthermore, Yang et al (48) demonstrated that MMP9 expression is associated with higher WHO grade, which is a key prognostic factor for patients with glioma. Recent evidence has also suggested that MMP9 has a distinct role in tumor angiogenesis, predominantly by regulating the bioactivity of vascular endothelial growth factor, which is considered the most promising factor in interfering with tumor angiogenesis and, thus, a novel therapeutic target (54). In the present study, the results suggested that miR-133a suppressed glioma cell migration and invasion via downregulation of MMP9. Therefore, miR-133a may be useful as a predictive value for early detection of tumor metastasis, and as a therapeutic target for suppression of human glioma invasion.

In conclusion, the present study is the first, to the best of our knowledge, to demonstrate that miR-133a is downregulated in human glioma, and contributes to cell proliferation, migration and invasion by directly targeting MMP9 in human glioma. The identification of candidate target genes of miR-133a may provide further understanding regarding the potential carcinogenic mechanisms in human glioma. The findings of the present study have therapeutic implications and may be exploited for further research into the treatment of human glioma. Future investigations are required to address whether
miR-133a may be useful in cancer treatment, and may be a potential therapeutic target for the treatment of glioma.

\section{References}

1. Xu Z, Zeng X, Tian D, Xu H, Cai Q, Wang J and Chen Q: MicroRNA-383 inhibits anchorage-independent growth and induces cell cycle arrest of glioma cells by targeting CCND1. Biochem Biophys Res Commun 453: 833-838, 2014.

2. Wen PY and Kesari S: Malignant gliomas in adults. N Engl J Med 359: 492-507, 2008.

3. Zhang C, Bao Z, Zhang W and Jiang T: Progress on molecular biomarkers and classification of malignant gliomas. Front Med 7: 150-156, 2013.

4. Wu H, Liu Q, Cai T, Chen YD, Liao F and Wang ZF: miR-136 modulates glioma cell sensitivity to temozolomide by targeting astrocyte elevated gene-1. Diagn Pathol 9: 173, 2014

5. Low SY, Ho YK, Too HP, Yap CT and Ng WH: MicroRNA as potential modulators in chemoresistant high-grade gliomas. J Clin Neurosci 21: 395-400, 2014.

6. Stupp R, Hegi ME, Mason WP, van den Bent MJ, Taphoorn MJ, Janzer RC, Ludwin SK, Allgeier A, Fisher B, Belanger K, et al; European Organisation for Research and Treatment of Cancer Brain Tumour and Radiation Oncology Groups; National Cancer Institute of Canada Clinical Trials Group: Effects of radiotherapy with concomitant and adjuvant temozolomide versus radiotherapy alone on survival in glioblastoma in a randomised phase III study: 5-year analysis of the EORTC-NCIC trial. Lancet Oncol 10: 459-466, 2009.

7. Stupp R, Mason WP, van den Bent MJ, Weller M, Fisher B, Taphoorn MJ, Belanger K, Brandes AA, Marosi C, Bogdahn U, et al; European Organisation for Research and Treatment of Cancer Brain Tumour and Radiation Oncology Groups; National Cancer Institute of Canada Clinical Trials Group: Radiotherapy plus concomitant and adjuvant temozolomide for glioblastoma. N Engl J Med 352: 987-996, 2005.

8. Haapasalo J, Hyartt A, Salmi M, Nordfors K, Lahtela SL, Kähkönen M, Helén P and Haapasalo H: Diagnosis and prognosis of gliomas - current prospects of molecular diagnostics. Duodecim 130: 893-901, 2014 (In Finnish).

9. Croce CM and Calin GA: miRNAs, cancer, and stem cell division. Cell 122: 6-7, 2005.

10. Bartel DP: MicroRNAs: Target recognition and regulatory functions. Cell 136: 215-233, 2009.

11. Hwang HW and Mendell JT: MicroRNAs in cell proliferation, cell death, and tumorigenesis. Br J Cancer 94: 776-780, 2006.

12. Ryan BM, Robles AI and Harris CC: Genetic variation in microRNA networks: The implications for cancer research. Nat Rev Cancer 10: 389-402, 2010.

13. Liu C, Liang S, Xiao S, Lin Q, Chen X, Wu Y and Fu J: MicroRNA-27b inhibits Spry2 expression and promotes cell invasion in glioma U251 cells. Oncol Lett 9: 1393-1397, 2015.

14. Wu D, Zhou Y, Pan H, Qu P and Zhou J: MicroRNA-99a inhibits cell proliferation, colony formation ability, migration and invasion by targeting fibroblast growth factor receptor 3 in prostate cancer. Mol Med Rep 11: 1469-1475, 2015.

15. Kuhn AR, Schlauch K, Lao R, Halayko AJ, Gerthoffer WT and Singer CA: MicroRNA expression in human airway smooth muscle cells: Role of miR-25 in regulation of airway smooth muscle phenotype. Am J Respir Cell Mol Biol 42: 506-513, 2010.

16. Baek D, Villén J, Shin C, Camargo FD, Gygi SP and Bartel DP: The impact of microRNAs on protein output. Nature 455: 64-71, 2008.

17. Ambros V: The functions of animal microRNAs. Nature 431: 350-355, 2004.

18. Sun YC, Wang J, Guo CC, Sai K, Wang J, Chen FR, Yang QY, Chen YS, Wang J, To TS, et al: miR-181b sensitizes glioma cells to teniposide by targeting MDM2. BMC Cancer 14: 611, 2014.

19. Ventura A and Jacks T: MicroRNAs and cancer: Short RNAs go a long way. Cell 136: 586-591, 2009.

20. Zhou Y, Wu D, Tao J, Qu P, Zhou Z and Hou J: MicroRNA-133 inhibits cell proliferation, migration and invasion by targeting epidermal growth factor receptor and its downstream effector proteins in bladder cancer. Scand J Urol 47: 423-432, 2013.

21. Tao J, Wu D, Xu B, Qian W, Li P, Lu Q, Yin C and Zhang W: MicroRNA-133 inhibits cell proliferation, migration and invasion in prostate cancer cells by targeting the epidermal growth factor receptor. Oncol Rep 27: 1967-1975, 2012. 
22. Kawakami K, Enokida H, Chiyomaru T, Tatarano S, Yoshino H, Kagara I, Gotanda T, Tachiwada T, Nishiyama K, Nohata N, et al: The functional significance of miR-1 and miR-133a in renal cell carcinoma. Eur J Cancer 48: 827-836, 2012.

23. Szafranska AE, Davison TS, John J, Cannon T, Sipos B, Maghnouj A, Labourier E and Hahn SA: MicroRNA expression alterations are linked to tumorigenesis and non-neoplastic processes in pancreatic ductal adenocarcinoma. Oncogene 26 : 4442-4452, 2007.

24. Chiyomaru T, Enokida H, Tatarano S, Kawahara K, Uchida Y, Nishiyama K, Fujimura L, Kikkawa N, Seki N and Nakagawa M: miR-145 and miR-133a function as tumour suppressors and directly regulate FSCN1 expression in bladder cancer. $\mathrm{Br}$ J Cancer 102: 883-891, 2010.

25. Ruebel K, Leontovich AA, Stilling GA, Zhang S, Righi A, Jin L and Lloyd RV: MicroRNA expression in ileal carcinoid tumors: Downregulation of microRNA-133a with tumor progression. Mod Pathol 23: 367-375, 2010.

26. Rao PK, Missiaglia E, Shields L, Hyde G, Yuan B, Shepherd CJ, Shipley J and Lodish HF: Distinct roles for miR-1 and miR-133a in the proliferation and differentiation of rhabdomyosarcoma cells. FASEB J 24: 3427-3437, 2010.

27. Du L, Borkowski R, Zhao Z, Ma X, Yu X, Xie XJ and Pertsemlidis A: A high-throughput screen identifies miRNA inhibitors regulating lung cancer cell survival and response to paclitaxel. RNA Biol 10: 1700-1713, 2013.

28. Chen X, Bo L, Zhao X and Chen Q: MicroRNA-133a inhibits cell proliferation, colony formation ability, migration and invasion by targeting matrix metallopeptidase 9 in hepatocellular carcinoma Mol Med Rep 11: 3900-3907, 2015.

29. Louis DN, Ohgaki H, Wiestler OD, Cavenee WK, Burger PC, Jouvet A, Scheithauer BW and Kleihues P: The 2007 WHO classification of tumors of the central nervous system. Acta Neuropathologica 114: 97-109, 2007

30. Tao J, Wu D, Li P, Xu B, Lu Q and Zhang W: MicroRNA-18a, a member of the oncogenic miR-17-92 cluster, targets Dicer and suppresses cell proliferation in bladder cancer T24 cells. Mol Med Rep 5: 167-172, 2012.

31. Nelson KM and Weiss GJ: MicroRNAs and cancer: Past, present, and potential future. Mol Cancer Ther 7: 3655-3660, 2008.

32. Kano M, Seki N, Kikkawa N, Fujimura L, Hoshino I, Akutsu Y, Chiyomaru T, Enokida H, Nakagawa $M$ and Matsubara $H$ miR-145, miR-133a and miR-133b: Tumor-suppressive miRNAs target FSCN1 in esophageal squamous cell carcinoma. Int J Cancer 127: 2804-2814, 2010.

33. Rao PK, Kumar RM, Farkhondeh M, Baskerville S and Lodish HF: Myogenic factors that regulate expression of muscle-specific microRNAs. Proc Natl Acad Sci USA 103 8721-8726, 2006.

34. Bostjancic E, Zidar N, Stajer D and Glavac D: MicroRNAs miR-1, miR-133a, miR-133b and miR-208 are dysregulated in human myocardial infarction. Cardiology 115: 163-169, 2010.

35. Moriya Y, Nohata N, Kinoshita T, Mutallip M, Okamoto T, Yoshida S, Suzuki M, Yoshino I and Seki N: Tumor suppressive microRNA-133a regulates novel molecular networks in lung squamous cell carcinoma. J Hum Genet 57: 38-45, 2012.

36. Nohata N, Hanazawa T, Kikkawa N, Sakurai D, Sasaki K, Chiyomaru T, Kawakami K, Yoshino H, Enokida H, Nakagawa $\mathrm{M}$, et al: Identification of novel molecular targets regulated by tumor suppressive $\mathrm{miR}-1 / \mathrm{miR}-133 \mathrm{a}$ in maxillary sinus squamous cell carcinoma. Int J Oncol 39: 1099-1107, 2011.

37. Wong TS, Liu XB, Chung-Wai Ho A, Po-Wing Yuen A, Wai-Man $\mathrm{Ng} \mathrm{R}$ and Ignace Wei W: Identification of pyruvate kinase type M2 as potential oncoprotein in squamous cell carcinoma of tongue through microRNA profiling. Int J Cancer 123: 251-257, 2008 .
38. Kinoshita T, Nohata N, Fuse M, Hanazawa T, Kikkawa N, Fujimura L, Watanabe-Takano H, Yamada Y, Yoshino H, Enokida $\mathrm{H}$, et al: Tumor suppressive microRNA-133a regulates novel targets: Moesin contributes to cancer cell proliferation and invasion in head and neck squamous cell carcinoma. Biochem Biophys Res Commun 418: 378-383, 2012.

39. Qiu T, Zhou X, Wang J, Du Y, Xu J, Huang Z, Zhu W, Shu Y and Liu P: miR-145, miR-133a and miR-133b inhibit proliferation, migration, invasion and cell cycle progression via targeting transcription factor Sp1 in gastric cancer. FEBS Lett 588: 1168-1177, 2014.

40. Qin Y, Dang X, Li W and Ma Q: miR-133a functions as a tumor suppressor and directly targets FSCN1 in pancreatic cancer. Oncol Res 21: 353-363, 2013.

41. Guo J, Xia B, Meng F and Lou G: miR-133a suppresses ovarian cancer cell proliferation by directly targeting insulin-like growth factor 1 receptor. Tumour Biol 35: 1557-1564, 2014.

42. Uchida Y, Chiyomaru T, Enokida H, Kawakami K, Tatarano S, Kawahara K, Nishiyama K, Seki N and Nakagawa M: miR-133a induces apoptosis through direct regulation of GSTP1 in bladder cancer cell lines. Urol Oncol 31: 115-123, 2013.

43. Chiyomaru T, Enokida H, Kawakami K, Tatarano S, Uchida Y, Kawahara K, Nishiyama K, Seki N and Nakagawa M: Functional role of LASP1 in cell viability and its regulation by microRNAs in bladder cancer. Urol Oncol 30: 434-443, 2012.

44. Li AY, Yang Q and Yang K: miR-133a mediates the hypoxia-induced apoptosis by inhibiting TAGLN2 expression in cardiac myocytes. Mol Cell Biochem 400: 173-181, 2015.

45. Feng X, Miao G, Han Y and Xu Y: CARMA3 is overexpressed in human glioma and promotes cell invasion through MMP9 regulation in A172 cell line. Tumour Biol 35: 149-154, 2014.

46. Yan Y, Liang H, Li T, Li M, Li R, Qin X and Li S: The MMP-1, MMP-2, and MMP-9 gene polymorphisms and susceptibility to bladder cancer: A meta-analysis. Tumour Biol 35: 3047-3052, 2014.

47. Roy R, Yang J and Moses MA: Matrix metalloproteinases as novel biomarkers and potential therapeutic targets in human cancer. J Clin Oncol 27: 5287-5297, 2009.

48. Yang X, Lv S, Liu Y, Li D, Shi R, Tang Z, Fan J and Xu Z: The clinical utility of matrix metalloproteinase 9 in evaluating pathological grade and prognosis of glioma patients: A meta-analysis. Mol Neurobiol 52: 38-44, 2015.

49. Stetler-Stevenson WG: Type IV collagenases in tumor invasion and metastasis. Cancer Metastasis Rev 9: 289-303, 1990.

50. Choi JY, Jang YS, Min SY and Song JY: Overexpression of MMP-9 and HIF-1 $\alpha$ in breast cancer cells under hypoxic conditions. J Breast Cancer 14: 88-95, 2011.

51. Aalinkeel R, Nair BB, Reynolds JL, Sykes DE, Mahajan SD, Chadha KC and Schwartz SA: Overexpression of MMP-9 contributes to invasiveness of prostate cancer cell line LNCaP. Immunol Invest 40: 447-464, 2011

52. Kumar B, Koul S, Petersen J, Khandrika L, Hwa JS, Meacham RB, Wilson S and Koul HK: p38 mitogen-activated protein kinase-driven MAPKAPK2 regulates invasion of bladder cancer by modulation of MMP-2 and MMP-9 activity. Cancer Res 70: 832-841, 2010.

53. Zhao J, Li G, Zhao Z, Wang J, Gao G and He S: Matrix metalloproteinase-9 expression is increased in astrocytic glioma and associated with prognosis of patients. Jpn J Clin Oncol 42: 1060-1065, 2012.

54. Du R, Lu KV, Petritsch C, Liu P, Ganss R, Passegué E, Song H, Vandenberg S, Johnson RS, Werb Z and Bergers G: HIF1alpha induces the recruitment of bone marrow-derived vascular modulatory cells to regulate tumor angiogenesis and invasion. Cancer Cell 13: 206-220, 2008 